\title{
Central Europe between the Great Powers: contemporary foreign-policy orientation
}

\author{
JAROSLAV UŠIAK ${ }^{1}$ - L'UBOMÍR KLAČKO - IVANA ŠOSTÁKOVÁ
}

\section{sciendo}

Politics in Central Europe (ISSN: 1801-3422)

Vol. 17, No. 1

DOI: $10.2478 /$ pce-2021-0007

\begin{abstract}
The main aim of this this study was to highlight the relations between the Central European countries (Slovakia, Czechia, Poland and Hungary) and the two great powers-the United States and the Russian Federation. We examined the importance of this region from a geopolitical perspective, analysing the relations between the Central European countries and the great powers through two of their critical manifestations: military bases and energy security. The selection of these themes was justified by the frequent centralisation of the abovementioned topics in political discussions and their role in underpinning the securitisation of political leaders. The analysis of government strategy papers, and politicians' statements and press releases, which included the views of three international relations experts, revealed diverse interstate relations. Each of the four Central European countries claims to be a responsible and reliable member of the North Atlantic Treaty Organization; however, not all of them place the same emphasis on this partnership. Regarding the energy sector, we came to the same conclusion. The countries declare their independence, but the RF continues to have a significant or dominant influence. The geographical position of the four surveyed countries is probably an important factor in this situation and the great powers generally adapt their foreign policy towards them accordingly, as evidenced by the selected topics. The results of the analyses confirmed the importance of this region from a geopolitical perspective.
\end{abstract}

Key words: Central Europe, U.S., Russia, energy, military bases, geopolitics

1 Coresponding author. 


\section{Introduction}

The political crisis in Ukraine, and the subsequent annexation of the Crimean Peninsula by the Russian Federation (RF) in spring 2014, placed the international community in a difficult situation. These events affected, and still affect, a wide range of policies and issues that are important for the functioning of states and their mutual relations. The United States (US), the Russian Federation and the international community - the European Union (EU) and the North Atlantic Treaty Organization (NATO) - play important roles in these relations. The EU member states and NATO are aware of their responsibilities towards the international community, which aims to maintain a united position regarding the above-mentioned events. The four Central European countries try to diplomatically express their own views on the situation without disrupting their bilateral relations with the RF and the US, but at the same time, both those countries attempt to manipulate the situation for their own benefit (Waisová 2020). In particular, the events in Ukraine of seven years ago intensified the interest and activities of both great powers in the region ${ }^{2}$. The four Central European countries were concerned and, naturally, reacted. As the title of the article indicates, we studied four selected Central European countries - Slovakia, Czechia, Poland and Hungary - and investigated the energy security and military bases in their territories as the means of shaping the relationships of these four countries with the aforementioned great powers.

Both topics are currently very attractive for both politicians and the media, because they are suitable for engaging voters. In both cases, money plays an important role. Presentation of the topics in the right light cannot only increase the desire for investment, but also infer financial savings for the public. Both options affect the stances of political actors. In the case of energy issues, the ecological approach is very typical (Waisová 2018), emphasising the reduction of the carbon footprint and promotion of renewable energy sources, with resulting changes in energy prices. People's own comfort is also an important factor; for example, in Slovakia alone, the 2009 energy crisis caused great concern among citizens regarding possible reduced gas supplies, and the population continues to be highly sensitive to changes in energy tariffs. The military theme also remains popular. Military bases, or the presence of foreign forces, are a constant topic in politics and among security analysts and the professional community. Opinions become heated during discussions about other countries' military bases in Central Europe - particularly those of the major geopolitical players,

2 We consider Russia in this article to be a great power, at least in the energy and military sectors. According to William Courtney and Howard J. Shatz (2020), Jeffrey Mankoff (2019) and Jeremy W. Lamoreaux (2021), the RF is still a great power, despite some problematic aspects (the economy, cooperation and the re-establishment of influence). Their statements are valid in relation to the energy and military (hard power) spheres of influence, and some of these authors have highlighted Russia's keenness to re-establish great power in all its aspects. 
which arouse strong opposition. In the public's opinion, their presence can either increase or decrease potential security risks, and public opinion is both contradictory and polarised. This controversy prompted the choice of the variables for this study: military bases and energy security.

The main aim of this study was to examine the nature and background of the approaches of the RF and the US towards the surveyed countries and vice versa, and to highlight the geopolitical importance of the Central European region in the context of these relations. In terms of geopolitics, we expect that the Central European region will continue to be an area of great power interest, due to its strategic geographical location.

In the first section of this article, we describe the literature review we conducted and the theoretical geopolitical framework of Harold Mackinder (1904) and Nicolas Spykman (1938), which underpinned the study. We obtained data regarding the foreign policy activities of the great powers and examined it using content analysis and we carried out a series of structured interviews. In two thematic sections, we describe the methods and results of the content analysis, structured interviews ${ }^{3}$ and comparative methods. In the final chapter, we draw conclusions and confirm the main premise of the study.

It may be asked why we did not include China's activities in the region. We chose not to investigate China's activities for two reasons. The first reason was that China is committed to pursuing its interests through economic instruments, which does not resonate in the societies of the surveyed countries as the topics of energy security and military bases do. Moreover, the relations of the selected countries with the two great powers, whether positive or negative, are more securitised than those with China.

The article covers three specific issues. First, it discusses the political approaches of the US and the RF towards the selected region, justifying the selection of the two issues (military bases and energy security) as topics for analysis. It then describes the chosen sectors, investigates national statements by the four Central European countries' representatives and explores the policies of the great powers. With regard to these issues, the opinions of Slovak analysts dealing with international and security policy will be presented. In order to achieve the most relevant and objective view of the research areas, we approached three independent analysts with different perspectives on the research areas. These analysts, from the non-government sector, had many years of experience, together with numerous publications and media appearances. The reason for incorporating their views into this work was to offer an opinion not influenced by security issues or the need to gain political points and voters' favour.

3 Structured interviews were conducted with experts on security from several institutions, emphasising their professional views on threats. All interviewees are experts in the areas of national and international security, with at least 10 years of experience. 
The literature used in the study was drawn mainly from a large number of internet sources, including periodicals, publicly accessible official government documents, press releases and the opinions of state officials. Due to the dynamics of the topic under review and its time limitations (for the article-relevant period, from 2014 until the middle of 2020), it was more appropriate and convenient to explore the topic using internet sources. Books did not describe the topics of interest in detail and it was unlikely that we would find a book that offered a summary of political views and statements on the issues. Books were, however, useful for learning more about the geopolitical theories of $\mathrm{H}$. J. Mackinder or N. Spykman and his followers, but the aim of the study was not to analyse and confirm or refute his theory. We referred to the part of it that geographically defined the Central European region and mentioned it as one of the key factors for gaining a dominant political and military position in the world.

\section{The attitudes of the US and Russia towards Central and Eastern Europe}

As stated in the Introduction, we did not analyse the theories themselves, but the main premises of the theories underpinning the overall conclusions and helped to provide a picture of what is happening in the field of international relations. Ištok analysed both theories in his publication Halford J. Mackinder a jeho teória Heartlandu (2014). The Heartland, according to the analyst's latest work, is a geographically delimited territory of the former Soviet Union (excluding the eastern part) comprising Western China, Mongolia, Afghanistan, Iran and Pakistan. Eastern Europe plays an important role in this theory, according to which whoever rules Eastern Europe rules the Heartland, and whoever rules the Heartland controls the World Island. If a coalition of states or a great power emerges, it is likely to threaten global stability. Mackinder divided Eastern Europe into three parts: Germany, Western Russia, and the countries between them (Czechia, Slovakia, Poland, Romania, Bulgaria, Greece and the southern Slav areas). In the theory, Eastern Europe plays an important role in the balance of power, since it is an arena for both sea and land powers, providing access to continental Eurasia (MacKinder, 1904) and making an RF-Germany alliance dangerous for the US. Rimland, in Spykman's theory (1938), is a country that surrounds the Heartland, encompassing the entire European peninsula, the Arab countries, the Indian subcontinent and the Far East. In the future, there is a risk that this area will be dominated by a single power, or a coalition of the Eurasian Rimland forces, which will control the Heartland; therefore, the issue of who controls Rimland is vital (Spykman, 1938). The two great powers, the US and the RF, seek domination (or attempt to prevent each other from gaining it) over Heartland and/or Rimland. 
Of course, every theory has its opponents. In particular, the American geographer M. I. Glassner criticised Mackinder for not taking into account the increasing power of the US, not explaining the contradiction of the powers controlling both the Heartland and the Soviet Union and ultimately failing to factor-in technological advances (Glassner, 1996). According to another American geographer, C. Flint, Mackinder created a theoretical basis for Cold War to justify the activities of one country (Flint, 2012). British geographer M. Blacksell criticised the simplification of such a complex phenomenon as the world order that has formed since the beginning of the Industrial Revolution (Blacksell, 2008). Polish geographer J. Barbaga pointed out the social Darwinism of Mackinder's theory and his overestimation of the political importance of large regions (Barbaga, 1978). The German G. Heyden also criticised Mackinder's theory, claiming that it was not scientific and that it aimed to provide justification for the British Empire conquering Russia (Ištok, 2014).

The abovementioned theories rest on the idea that the world's great powers big geopolitical players - are trying to gain as much influence and control as much territory as possible, using all possible tools (in our case, military bases and energy security).

The US Security Strategy of 2017 declared that the RF is trying to weaken US influence in the world and subvert the US's alliances and friendships, because the RF perceives NATO and the EU as a threat. A strong and free Europe is very important for the US (Řádek, 2017a, 2017b). To counterbalance the negative effects of the RF, the US seeks to maintain an important position in the energy sector, where it is interested in diversifying energy sources. In the area of security, it is fulfilling its NATO commitments and expects the same from its European partners, which should allocate $2 \%$ of their GDP to defence spending (National Security Strategy..., 2017). The Strategy remains central to intelligence analyses that aim to assess world threats, and it identifies the RF as one of those threats. EU countries may become more susceptible to the influences of the RF and China after the UK leaves the EU, because of the economic fluctuations caused by its departure. The UK is a strong opponent of the RF, but some countries seek to soften the sanctions and look for opportunities to invest in the RF. Disagreements in the transatlantic environment, and an increase in the influence of anti-systemic political entities, could be used by the RF to the detriment of the US (Worldwide threat assessment..., 2019). In February 2019, US Vice-President Mike Pence, at a security conference in Munich, urged all partners to honour their commitments to NATO. This would strengthen NATO again and make the US stronger than its partners. NATO will face down any attempts to subvert its influence through political interventions or energetic blackmail. The US greatly appreciates European countries, as well any other countries that stand against 
the Nord Stream II project ${ }^{4}$ (remarks by Vice President..., 2019). Increased interest in Central European countries has also been confirmed by the visits of US Secretary of State Mike Pompeo in February 2019 to Hungary, Slovakia and Poland. In addition, the White House hosting the Prime Ministers of Czechia, Slovakia and Hungary, and the Polish President, have clearly signalled that the US is interested in restarting and strengthening relations. At a press conference in Hungary, Mike Pompeo noted, that the prolonged absence of the US from the Central European region, which has been evident over the past few years, is unacceptable (Istrate, 2019).

Paradoxically, the RF also wants a stable and strong EU. They blame the US for over-engagement in NATO and involving EU countries in disputes resulting in economic sanctions. The RF's National Security Strategy declared that it advocates the consolidation of mutually beneficial cooperation with European states and the EU, the harmonisation of integration processes in Europe and the post-Soviet areas, and the formation of a Euro-Atlantic collective security agreement with a clear treaty and legal basis. Activities relating to the development of NATO's military scope, the strengthening of the military activities of member states, the potential growth of NATO and the proximity of military infrastructure to the RF border are major threats to the RF.

The RF is prepared to develop relations with NATO for the purpose of strengthening general security in the Euro-Atlantic region, on the condition that the interests of the RF are considered when conducting military and/or political planning, and that the provisions of international law are respected. At the Munich Security Conference in Germany, The RF's Minister of Foreign Affairs, noted that after the Cold War, no NATO-centrism existed. The commitment to not reinforcing the security of one country at the expense of another was also forgotten, even though it was approved by the Organization for Security and Co-operation in Europe (OSCE) and the RF-NATO Council. The potential of OSCE was not used to enhance cooperation between the RF and the EU; instead, European countries were dragged towards a confrontation with the $\mathrm{RF}$, which resulted in economic sanctions and billions of euros in losses. He also underlined the words of President Putin that the RF valued a strong and independent EU and understood the efforts of the EU to achieve self-sufficiency and sovereignty in defence and security. This is a legitimate idea in the context of strengthening the multipolar world order (Lavrov, 2019), which is one of the reasons why President Putin advocated the Nord Stream project to increase the energy security of Europe as a whole and both RF and Germany (Putin, 2019). Official energy documents have acknowledged the efforts of the EU states (including the four surveyed countries) to diversify energy sources and, therefore,

4 The Nord Stream II project is a pipeline that will bring natural gas to Western Europe from Russia, especially to Germany, the pipeline stretches across the Baltic Sea. 
reduce the risk of disrupted supplies (by, for example, the conflict in Ukraine). Consequently, the RF is endeavouring to build a new gas pipeline to maintain its dominant position as a supplier. According to the energy company Gazprom, which is controlled by the Russian government, the European market is one of the key consumers of natural gas and the RF has been the largest exporter to Europe for last 50 years. It supplies gas to Central and Western Europe through long-term contracts at the intergovernmental level, based on the principle of 'take or pay', which guarantees financial compensation in the event of failures of energy supply. In 2018, Gazprom exported 9.9 billion $\mathrm{m} 3$ of gas to Poland, 6.5 billion $\mathrm{m} 3$ to Czechia; 7.7 billion $\mathrm{m} 3$ to Hungary and 5.1 billion $\mathrm{m} 3$ to Slovakia (Gazprom, 2019).

Based on the analysis of the abovementioned official government and state documents, and statements by representatives of RF and US we concluded that the two chosen variables (energy security and military bases) best represented the great powers' influence in the region. In the case of the RF, economic cooperation was prioritised; in the US, the military option. To a degree, the energy theme is an ace in the hands of President Putin. All the surveyed countries rely on RF energy providers, even if they pursue partial diversification. The RF comprehensively questions the importance of NATO and criticises its unnecessary expansion and proximity to the RF's borders. The US has a weaker position in the energy field, so it primarily plays with a military card. It benefits from the fact that all four countries are NATO member states. The fact that the US lacks energy dominance in the region was confirmed by President Trump's efforts to impose sanctions on the countries that are involved in the Nord Stream project.

The geopolitical theories have proven to be applicable even in today's world, and it is clear that the US and the RF are aware of the geographical importance of the Central European region and the individual countries within it. In the next two sections, we analyse the extent of the influence of the great powers on the four surveyed countries through the two specified variables.

\section{Military bases in Central European states}

Recently, discussions have revived regarding the establishment of military bases in Central European countries and, in our opinion, a certain level of awkwardness is involved. The US is negotiating possible defence cooperation agreements with individual countries, with contracts to be based on the modernisation and construction of their military infrastructure, which (if necessary) would be helpful and accessible to all NATO member states. This is one of the arguments in favour of contributing to NATO. It is difficult to say whether the US has a hidden agenda and the whole process is mainly due to power-orientated interests in the region or its interest in Europe's security. 
In his article, Vladimír Šnídl (2015) presented the opinions of experts (Marián Majer and František Šulc) regarding the presence of foreign troops in Europe. US troops in Europe are subject to a dual-function commander, who is always American, while the NATO headquarters are located in Belgium. The commander commands US troops, but can also command NATO troops. NATO has neither its own army nor a military base; in a sense, every military base of a NATO member state is a NATO base. The organisation builds only headquarters or training centres consisting of representatives of the member states. In today's world of hybrid threats, having a permanent base with thousands of soldiers has no tactical importance; it is largely a symbolic gesture. The key to securing logistics for military units is to have both the financial and technical means to move the units around. The US had ambitions to establish missile defence facilities in Czechia and Poland, but eventually, after Barack Obama's accession to office, the US withdrew from talks due to the RF's objections. In the context of the Ukraine crisis and the annexation of the Crimean peninsula, the US and NATO preferred extensive exercises and Rapid Deployment Force commands (Šnídl, 2015).

The building of foreign military bases in Slovakia is a topic that incites heated debate among politicians. In relation to NATO, the establishment of NATO Force Integration Units (NFIUs) provoked this debate. The first NFIU was activated in Slovakia on 1 September 2016. All NFIUs are components of NATO's military structure (the NATO force structure) and answer to the Supreme Allied Commander Europe (SACEUR).

Former Prime Minister R. Fico initially declared that he would not allow the establishment of NATO military bases in Slovak territory. However, he later softened the argument by conceding that, if the units' purpose was logistics and training, it would not be a major problem, but if NATO wanted to establish bases with combat personnel, the answer would be 'no' (TASR, 2014). The former President Andrej Kiska offered construct NATO a logistics centre in Poprad in 2014, which was meant to serve as an ammunition depot. Former Prime Minister Fico had already announced that, if the NATO tried to set up a base with soldiers, he would revoke the concession and he would initiate the referendum. (Slovak PM follows..., 2014). Currently, the topic of defence cooperation with the US is prominent in Slovakia. The conclusion of the agreement would benefit both NATO and the European Deterrence Initiative, and there have been suggestions that the provision of funds for the restoration of airports in Sliač and Kuchyňa would be a precondition of such an agreement. The draft treaty also mentions the construction of ammunition depots in Záhorie, which triggered stormy responses across the entire political spectrum. The Slovak coalition government's partners are not completely united; hence, they seek compromise and aim to please their voters. Minister Miroslav Lajčák believes that the adoption of such an agreement would increase Slovakia's foreign credit, and the US 
understands that the treaty would only be a framework and that any proposals would have to be approved by the Government of Slovakia and the National Council of Slovakia (NCS). Meanwhile, the conditions are under discussion and nothing is certain. Other NATO member states have also concluded such agreements. Slovakia's former Prime Minister Peter Pellegrini confirmed the words of Former Minister Lajčák that nothing is agreed and that, if the conditions are disadvantageous and compromise Slovakia's sovereignty, nothing will be signed. Slovakia must not forget that it is a NATO member, which involves not only benefitting from the advantages, but offering something in return. The Slovak National Party has argued that the government has no mandate for a treaty that mentions the construction of ammunition depots and the expansion of airport areas (Pellegrini tvrdí, že..., 2019). The chairman, Andrej Danko, stated in one discussion that the Ministry of Foreign Affairs is misleading citizens and will insist that the treaty is unacceptable for Slovakia (Danko v súvislosti..., 2019). In March 2020 Slovakia received a new, pro-NATO orientated government, but at the time of the COVID-19 crisis, the question of NATO military bases in Slovakia was not on the agenda.

In Czechia, the US wanted to set up a radar station as part of the US Missile Defence system. Although President Obama's administration abandoned this intention, President Milos Zeman opposed it, calling it unnecessary, and pointed out that the RF could perceive it as a threat to its national security and take countermeasures. If the Czech government had decided to go ahead, Czech president M. Zeman would have been a strong opponent, since he wanted no foreign army on Czech territory (Rozhovor prezidenta republiky..., 2015). Former Czech Prime Minister Bohuslav Sobotka would not have authorised a base with foreign troops or supported an increase of NATO's military presence in Europe (Slovakia and Czech, 2014), but the current prime minister is an advocate of Czechia's membership of NATO. At a meeting between the prime minister Andrej Babiš and NATO Secretary General Jens Stoltenberg, A. Babiš was praised for promising to increase defence spending on 2\% GDP by 2024 (Secretary General praises..., 2018).

Hungary seems to have settled the question of military bases. There is an air base on Hungarian territory, in the city of Pápa, which serves NATO's strategic air transport needs. Hungary, together with other SAC countries (Strategic Airlift Capability members' states), has invested in the development of this base to support strategic airlift capability. It is in Hungary's interests to continue to develop the base as an important, common, multi-purpose centre that can satisfy national and European requirements, as well as those of the NATO and SAC countries (Pápa Air Base..., 2019). A small NFIU, similar to the one in Slovakia, was established in Székesfehérvár in 2016. Although Hungary's Prime Minister Viktor Orbán considers NATO to be important, he believes that in matters of military security Hungary should mainly rely on its own capacity and deal with 
military threats using primarily its own forces (Bayer, 2019). The Hungarian government signed a defence cooperation agreement with the US in Washington on NATO's $70^{\text {th }}$ anniversary. This Treaty provides a suitable platform for further strengthening mutual cooperation in the defence sector. At the same time, the signing of the Treaty confirmed good mutual relations and trust between the two countries, and their confidence that they can rely on each other (MFAT, 2019).

Of the sample countries chosen for the research, Poland is without doubt the country with the highest number of military bases, whether they are NATO or US bases. Despite this presence, Poland plans to have approximately 200,000 of its own soldiers in active service by 2025 and is actively arming, since it is in a state of potential conflict with the RF. Poland's efforts to establish a permanent US base in its territory are understandable and they have been underlined by the offer of the Polish government to provide a 10-year 2 billion US dollar subsidy to support the presence of the US Army. These efforts are also supported, almost unanimously, by the political elites and the majority of the population. Poland plans to pay the operational expenses of the permanent US base from its defence budget (Kamiński, 2019). Even without these efforts, several NATO headquarters and training centres have been located in Poland as part of a deterrence and defence project. The Multinational Corps Northeast Headquarters is located in Szczecin and there is a Joint Force Training Centre in Bydgoszcz. The Multinational Division Northeast Headquarters is based in Elblag, coordinating and overseeing the training and preparation of four battle groups (Deterrence and defence, NATO..., 2019).

Opinions of Analysts' A, B, C during the structured interviews: Military bases in the Central European countries are also a sensitive topic in relation to the Ukrainian crisis. Yet again, Poland is the most evident example in this sphere, more active than other Central European countries. Czechia could have been part of the US Missile Defence system, but the previous government vetoed such a move. Hungary hosts a NATO air base and an NFIU logistics unit, as does Slovakia. Again, this situation relates to economic interests. From a long-term strategic perspective, it does not matter whether the specific bases on the countries' respective territories are populated by soldiers of other member countries or whether they are engineering units, artillery brigades or serve other functions. All these countries are members of NATO and, from the point of view of the RF, NATO is an 'enemy'. Regarding troop movements in the event of armed conflict, the corridor leading through the territory of Poland is particularly important. The second most important route is the Danubian route running through Hungary. Slovakia, and to a degree Czechia, are unimportant for this purpose.

With reference to the previously mentioned politicians' views and data, we have outlined the Central European region's overall significance from a military point of view, showing the most important country to be Poland, which strives 
to be more or less a leader in this field. It hosts US troops and pays part of the cost on its own initiative. Slovakia and Czechia are more cautious, claiming NATO membership and calling themselves reliable partners, while the issue of NATO bases divides not only politicians, but the respective societies. The loss of prestige if these countries withdrew from NATO membership would harm both countries on several levels. The historical situation also affects the whole situation. Hungary, we concluded, 'plays on both sides' by hosting a NATO base and entering into cooperation, but declaring its intention to rely mainly on its own resources. Overall, individual countries seem to largely oppose the RF and favour the US.

\section{Energy security issues in Central Europe}

The gas crisis of January 2009 demonstrated the importance of energy security, which all four studied countries realised. After this crisis, the European institutions and the EU member states started to adopt and implement new measures to prevent supply disruptions. The persistent Russian-Ukrainian conflict once again raised questions about the stability of the natural gas and oil supply from the RF through Ukraine. Moreover, it is now necessary to analyse energy security in environmental terms. All four of the studied countries agreed on a declaration to diversify energy sources and the energy mix with regard to electricity production; however, each country more or less defines its own conditions (i.e. selects its own energy providers and manages its own electricity production in its own way).

Slovakia, in the event of a failure of gas transit through Ukraine, is ready to import gas from other sources, such as gas flowing from Czechia and Western Europe. A connection with Poland is also under construction, which will allow gas to be drawn from Norway, Qatar and the US shale regions. In 2015, pipeline connections with Hungary became operational, allowing Slovakia to draw gas from the Croatian LNG terminal in Omišalj. The meeting of Slovakia's Former Prime Minister Petr Pellegrini and Russia's Former Prime Minister Dmitri Medvedev presented an optimistic forecast for Slovakia's energy security, since the Russian Prime Minister promised that Slovakia could count on the RF as a gas supplier after the beginning of 2020. Failure of the gas transportation would be unwelcome, not only for Slovakia, but for the whole EU, because EU gas consumption is increasing and the Nord Stream 2 project will not be completed until the end of 2020 (Medvedev assures..., 2019). Both sides are looking for ways to collaborate and connect the Nord Stream 2 and Turkstream infrastructure projects to Slovakia (Russia proposes..., 2019). Slovakia is 100\% dependent on oil imports from the RF via the Druzhba pipeline, which starts in the RF and ends in Czechia. The transport capacity in Slovak territory is 20 million tons per year. An 8.5 kilometre stretch of the Adria pipeline, which starts in the Croatian town of Omisajl, crosses Slovak territory. It was built in 
1980 as a potential diversion route for supply; hence, when flow from Croatia is not used, the pipeline transports Russian oil to the south under the aegis of Transpetrol, the Slovak oil pipeline company. The construction of the BratislavaSchvechat pipeline has not yet started, due to opposition from self-government and activists. Slovakia is also entirely dependent on imports of nuclear fuel from the RF. Replacement by any other type of fuel would be technologically difficult and time-consuming, and would result in financial losses. After negotiations between Slovak and RF delegations, a Memorandum of Understanding was signed between the Ministry of the Economy of Slovakia and the Russian company Rosatom, regarding the peaceful uses of nuclear energy, which include the fact that it is carbon-free and helps in the fight against global warming (MH SR, 2019). At the same time, a contract was signed between Slovak power plant companies and Rosatom's TVEL Fuel Company for the supply of nuclear fuel over the period 2022-2026, with the possibility of extension until 2030 (Rosatom will continue..., 2019).

Similarly, Czechia's Prime Minister Andrej Babiš identified nuclear energy as very important for the production of electricity for the purposes of reducing greenhouse gases and guaranteeing energy security. In this respect, Czechia also cooperates with the US (ÚV ČR, 2018). A. Babiš is also in favour of new types of nuclear units (for the Dukovany nuclear power plant) being financed by ČEZ Group ${ }^{5}$, unlike the situation in Hungary, where new nuclear power units in Paks will be built by Rosatom with the help of a financial loan from the RF (Strojaščejesa AES, 2019). This initiative was defended by Czech President Milos Zeman, but it is a complex project, which involves the ČEZ Group and the State seeking the most appropriate way of constructing new blocks of nuclear power plants. At present, Czechia operates six units of nuclear power plants (two in Temelín and four in Dukovany) and imports nuclear fuel from the RF, even though it used fuel from the Westinghouse company in the past (Národní akční plán..., 2015).

Czechia is in a different position in terms of diversification and contracts for the importation of gas and oil supplies. In the medium term, despite the increasing amount of purchased gas on European exchanges, gas from Russia will continue to be Czechia's main source of supply. In the long term, the situation will affect the supply of LNG from the US and Canada, as well as increased gas imports from the RF. Depending on circumstances, it is estimated that Czechia may remain dependent on gas supplies from the RF until 2050 (Zpráva o očekávané dlhodobé, 2016). Czechia receives oil through two pipelines: the Druzhba pipeline from the RF and the IKL pipeline from Germany. In a 2016 report, the Czech Ministry of Industry and Trade stated that $64.6 \%$ of the oil was transported via the Družba

5 ČEZ Group is one of the largest energy companies in Europe, where the major shareholder of ČEZ's company is the Czechia. 
pipeline and $35.4 \%$ via the IKL one. The origins of the oil were $64.30 \%$ from the RF and 27.96\% from Azerbaijan (Ropa a ropné produkty, 2016).

Poland is dependent on gas imports from the RF under the Yamal contract, which expires in 2022. According to the statistics of Polish Oil Mining and Gas Extraction (PGNiG, the Polish state energy company), imports of natural gas in 2017 from the east amounted to 9.7 billion cubic meters $(9.7 \mathrm{bcm}$; Integrated Annual Report, 2017); however, Poland has signed several contracts for imports of liquefied natural gas (LNG) from the US. This move has reduced Poland's dependence on RF gas and thus strengthened the country's energy security (US, Poland sign, 2019). Reduced dependence on the RF is also evident with regard to oil imports. As reported by the state-run ORLEN refinery, about $50 \%$ of the processed oil does not currently come from the RF. The exporting countries are Saudi Arabia, Nigeria, Angola and Norway. Saudi Arabia alone delivers 400,000 tons of oil per month (Half of crude oil..., 2019). Regarding nuclear energy, Poland is planning the introduction of six nuclear power plants, which should be operating from 2033 to 2043, with mainly Polish actors participating in the project. These nuclear power plants represent a commitment to producing carbon-free energy (energy policy of Poland until 2040).

Hungary's Ministry of Foreign Affairs and Ministry of Trade presented their opinions to Francis R. Fannon, the US Secretary of State and head of the US Bureau of Energy Resources on their meeting in December 2018. They stated Hungary's intention to meet its energy requirements from multiple sources not for economic reasons, but for national security ones. Former Hungarian Minister of Foreign Affairs and Trade Peter Szijjártó released a memo that the country had already taken the necessary measures and asked the US to cooperate with other Central European countries to improve energy supplies to the region (Péter Szijjártó holds..., 2018). The Minister also concluded an agreement with the Russian company Gazprom for gas supplies, even though the RF and Ukraine had not agreed on a contract that would expire at the end of 2019. Hungary takes a proportion of its gas from Austria and relies on future long-term contracts from the south suppliers. He pointed out that Gazprom is working with Bulgaria and Serbia to supply gas through the TurkStream pipeline (Hungary's gas supply..., 2019). Among other initiatives, Hungary either cooperates or negotiates with Slovenia, Croatia and Cyprus on bilateral energy projects.

Hungary imports a large proportion of its consumed oil via the Druzhba pipeline from the RF, and another proportion via the Adria pipeline. Crude oil production will increase in the near future, because new oil deposits have been discovered in the west part of RF. Regarding nuclear power, Hungary plans to put the Paks nuclear power plant into operation. Former Minister Szijjártó highlighted the cooperation between the RF and Hungary, thanks to which the power plant will supply about 80,000 households with energy (Hungarian-Russian relations..., 2018). Currently four nuclear reactors supply the country 
and another two are planned for launch in 2025. All fuel is supplied by the RF through the TVEL Fuel Company. In preparation for the launch of two additional reactors, the EU's Euratom Supply Agency (ESA), backed by the European Commission (EC), commented that if the supply of nuclear fuel failed, there would be no available alternative fuel. The dispute has been resolved and a fuel supply contract has been signed for a period of 10 years instead of 20 , with the expectation that, in the short term, alternative fuel will become available on the market. Hungary has started cooperating with other Central European Countries in the field of nuclear energy in terms of capacity and infrastructure (WNA, 2019).

Opinions of Analysts' A, B, C during the structured interviews: Regarding energy security, gas imports and the main energy providers were mentioned most frequently by the analysts. The RF holds an important position as a major exporter of gas throughout Europe, but the US is seeking, and in some cases concluding, agreements to export its shale gas and LNG. There is also the possibility of a South Stream pipeline; however, the price of such a pipeline must be competitive with RF gas and warrant the financial investment for the building of the infrastructure. Each country handles this issue independently, according to its main source of supply and choice of energy providers. The Nord Stream 2 project has polarised the international community; however, it does not jeopardise the supply of RF gas to Europe via Ukraine as has been alleged. Germany will not only be the destination of the pipeline, but also one of the main consumers of the gas. In less than 10 years, Germany will need alternative sources of energy, due to the closure of its nuclear and coal-fired power plants. The transmission capacity that will be provided by both the Nord Stream pipelines will not cover Germany's gas consumption; hence, gas will continue to flow from Ukraine.

Again, as with the previous section, it was possible to study the different intensities of efforts to cooperate with the RF or the US and, again, Poland was the most striking country in this respect. Hungary receives gas supplies from several sources, but in the field of nuclear power it primarily deals with the RF. Slovakia is dependent on Russian energy and long-term contracts have been agreed with the RF, but for the time being, this appears to be a stable and profitable arrangement. ${ }^{6}$ Czechia is trying to lessen its dependence on the RF, but at least in the field of nuclear power, it is likely to continue buying fuel from the RF. Despite the relatively extensive diversification of resources, there continues to be a perceptibly strong influence of the RF in the Central European region. This influence in the region is also likely to be intensified by Germany's increased demand for Russian gas, due to its energy reform policies: when there is an available, cheap, and easily accessible supply, particularly of gas, the Central European countries will buy it.

6 Another fact that ensures the flow of gas from Ukraine is that the Slovak gas industry invested about 300 million euros in the Ukraine gas field and obtained a licence for this field for 30 years. 


\section{Conclusion}

In previous sections, we discussed the various thematic areas in relation to the foreign policies of the surveyed countries. The thematic areas were analysed especially in the context of relations between the studied countries and the great powers of the US and the RF. We also paid attention to the opinions of members of the professional community who independently and objectively evaluated these relations and, thus, helped to provide a coherent picture of the relations and supported the achievement of the research goal. Based on the analysis, we concluded that the two great powers are aware of the importance of this region. The US is very active in the region, as confirmed by recent visits by the US secretary of state, Mike Pompeo, to three of the observed countries, as well as individual visits by these countries' prime ministers and the Polish president to the White House. The end of President Obama's term of office heralded US efforts to restore good relations with the Central European region. The US is engaged in both the areas addressed by this study. The military is a top priority, but the US is trying to increase its involvement in the energy sector through sanctions and by exporting LNG. By contrast, the RF is heavily involved in the energy sector, due to its dominant position in the Central European energy market. In most of the observed countries, it is also involved in the development of nuclear energy.

With regard to energy security, the surveyed countries clearly supported the diversification of sources and the reduction of their carbon footprints; the countries are collectively prepared for shortfalls in gas supplies. They welcome US activity in the area regarding gas supply, but it is important to determine who supplies whom, which countries are transit countries, and who the final customers might be. Ultimately, availability and price will be the determining factors of this, but the RF continues to be important as a supplier of both gas and oil. In three of the four surveyed Central European countries, the RF is the main partner for nuclear energy; however, Poland is likely to count on the Western countries, or Central European cooperation, with regard to nuclear energy.

The situation regarding military bases is quite different. All the surveyed countries claimed to be reliable and responsible NATO members. Approaches that confirmed these claims differed in each country and, sometimes, politicians made specific statements or took specific actions. Militarily, Poland is the leading and most active NATO member in the Central European region, followed by Hungary, Slovakia and Czechia. In Slovakia and Czechia, the historical context and long-term negative experiences associated with the presence of troops play an important role in the situation.

The aim of this article was to examine the approaches of the RF and the US and their relations with the surveyed countries (and vice versa), and also to highlight the geopolitical importance of the Central European region. Both great 
powers have interests in the region and are affecting all four countries through energy and military 'cooperation', as declared in their official documents. The level of cooperation with the great powers differed in each observed country. It was also influenced by the historical development of individual countries, their current political situations and geopolitical developments. The terms of cooperation can be understood as efforts by both the great powers to gain influence within the selected countries. The US and the RF watch each other's moves in the field of foreign policy very closely and, according to the situation, adapt their foreign policies regarding countries in the region. This conclusion was partly confirmed by the analysts in the section concerning military bases, which also defined the importance of each country in respect of military campaigns. The most important geographical location is Poland, followed by Hungary, Slovakia and Czechia. The countries seem to be aware of this fact and approach the great powers accordingly. Poland has most negative attitude towards the $\mathrm{RF}$ and is most engaged in cooperation with the US. According to statements by Hungarian politicians about the two great powers, we assume they are in balance in relation with RF and US. Slovakia and the Czechia are committed to Euro-Atlantic cooperation, but some politicians' statements and actions cast doubt on this commitment. The Central European region is important for both powers, otherwise the US would not engage militarily in Poland and propose defence cooperation agreements with other countries in the region. In addition, the US is making an effort to challenge the energy dominance of the RF in the region, by exporting LNG to Poland and imposing sanctions on the countries involved in the Nord Stream 2 project.

This article stated that we did not want to confirm or refute the mentioned geopolitical theory. The study's conclusions highlighted that control of the largest possible area is very important. This was also confirmed by the recent activities $^{7}$ of both US and RF leaders and we concluded that the theory applied strict realism to international relations, with actors trying to control and influence as much territory as possible. In our case, we considered the territory (area) of Central Europe - which play, and will continue to play, an important role in either of the two great powers' overall dominance, since they use resources in their efforts to eliminate or partially restrict each other.

\section{References}

Barbag, Jozef (1978): Geografia polityczna ogólna. 3. wyd. Warszawa: Panstw. Wyd. Nauk.

7 Il/legal annexation of the Crimea: Trump's statements on purchasing Greenland. 
Bayer, Lily (2019): Orbán: Hungarian military should be able to defend country 'from any direction', Politico: available at https://www.politico.eu/article/orban-hungarian-military-should-defend-country-from-any-direction-mike-pompeo-russia/ (14 February 2019).

Blacksell, Mark. (2008): Geografia polityczna. Warszawa: Panstw. Wyd. Nauk.

Bude u nás vojenská základna USA? Babiš, Schwarzenberg, Bělobrádek, Škromach, Okamura a mnozí další odpovídají. Zazněly i vzkazy pro Sašu Vondru... (2015): parlamentnilisty.cz: available at https://parlamentnilisty.cz/arena/monitor/Bude-u-nas-vojenska-zakladna-USA-Babis-Schwarzenberg-Belobradek-Skromach-Okamura-a-mnozi-dalsi-odpovidaji-zaznely-ivzkazy-pro-Sasu-Vondru-369049 (12 June 2019).

Česko nechce íst' pri stavbe jadrových blokov mad'arskou cestou, Pravda (30 November 2018): available at https://spravy.pravda.sk/ekonomika/clanok/493590-cesko-nechce-ist-pri-stavbe-jadrovych-blokov-madarskou-cestou/ (7 June 2019).

Courtney, William and Shatz, Howard J. (2020): Why Russia Struggles to Feed Its Great-Power Addiction, available at: https://www.rand.org/blog/2020/05/why-russia-struggles-to-feed-its-great-power-addiction.html.

Danko v súvislosti s USA uviedol podl'a ministerstva viacero nepresností (2019): SITA 1 (Slovenská tlačová agentúra): available at https://domov.sme.sk/c/22075719/danko-v-suvislosti-s-usa-uviedol-podla-ministerstva-viacero-nepresnosti.html?ref=av-left (3 June 2019).

Deterrence and defence, NATO on the MAP (2019): available at: https://www. nato.int/nato-on-themap/\#lat=53.82956409702528 \& lon=16.4537772

27630567 \& zoom $=2$ \& layer-5 (4 June 2019).

Diversification of gas supply sources, Integrated annual report 2017 (2018): available at http:// en.pgnig2017.pl/otoczenie-i-interesariusze/rola-pgnig-w-zapewnieniu-bezpieczenstwa-energetycznego/dywersyfikacja-kierunkow-dostaw-gazu/ (10 June 2019).

Duda, Andrzej (2016): Europe must demand that Russia leave Crimea, 112UA: available at: https://112.international/ukraine-top-news/andrzej-duda-europe-must-demand-that-russia-leave-crimea-3679.html (31 March 2016).

Dyduch, Joanna and Skorek, Artur (2020). Go South! Southern dimension of the V4 states' energy policy strategies - An assessment of viability and prospects. Energy Policy, 140/May 2020, https://doi.org/10.1016/j.enpol.2020.111372.

Energetičeskaja strategia Rosii na period do 2030 goda, Ministry of Energy of the Russian Federation (2009): available at https://minenergo.gov.ru/node/1026 (10 June 2019).

Energy policy of Poland until 2040 (2018): available at: https://www.gov.pl/documents/33372/436746/EN_Extract_EPP2040.pdf/ca2760d6-f9ab-9a87-c3a9-61063abe3681 (10 June 2019).

EU a NATO připomněly, že nadále neuznávají ruskou anexi Krymu, ČTK České noviny (2019): available at https://www.ceskenoviny.cz/zpravy/eu-a-nato-pripomnely-ze-nadale-neuznavaji-ruskou-anexi-krymu/1734464 (5 June 2019).

EÚ nemá silného vodcu ako Rusko, Čína alebo USA, povedal Zeman pre ruskú televíziu, HNonline (2018): available at https://hnonline.sk/svet/1856497-eu-nema-silneho-vodcu-ako-rusko-cina-alebo-usa-povedal-zeman-pre-rusku-televiziu (05 June 2019). 
Flint, Colin. (2012). Introduction to Geopolitics, London: Routledge.

Foy, Henry (2018): Orban thanks Putin for help in overcoming EU sanctions impact, Financial Times: available at https://www.ft.com/content/Ofdf08cc-bb37-11e8-94b2-17176fbf93f5 (9 June 2019).

Gazprom, Europe (2019): available at https://www.gazprom.com/about/marketing/europe/ (6 June 2019).

Glassner, Martin. I. (1996). Political Geography. $2^{\text {nd }}$ ed. New York: J. Wiley.

Half of crude oil imported by Poland comes from outside Russia, Poland In (2019): available at https://polandin.com/42179993/half-of-crude-oil-imported-by-poland-comes-from-outside-russia (10 June 2019).

Hungarian-Russian relations are developing again, Website of the Hungarian Hungarian Government - Ministry of Foreign Affairs and Trade (2018): available at https://www.kormany.hu/en/ ministry-of-foreign-affairs-and-trade/news/hungarian-russian-relations-are-developing-again (12 June 2019).

Hungary supports Ukraine's territorial integrity, Website of the Hungarian Government - Ministry of Foreign Affairs and Trade (2018) available at: https://www.kormany.hu/en/ministry-of-foreign-affairs-and-trade/news/hungary-supports-ukraine-s-territorial-integrity (12 May 2019).

Hungary's gas supply is also assured for next year, Website of the Hungarian Hungarian Government - Ministry of Foreign Affairs and Trade (2019): available at https://www.kormany.hu/en/ ministry-of-foreign-affairs-and-trade/news/hungary-s-gas-supply-is-also-assured-for-next-year (13 June 2019).

Ištok, Robert. (2014): Halford J. Mackinder a jeho teória Heartlandu, Folia geographica 56 (1): 19-45. Istrate, Dominik (2019): The US has not given up on Central Europe: available at https://emerging-europe.com/intelligence/the-us-has-not-given-up-on-central-europe/.

Kamiński, Krzysztof (2019): U.S. Permanent Military Base in Poland, Warsawinstitute: available at: https://warsawinstitute.org/u-s-permanent-military-base-poland/.

Kulikadis, Thomas (2018): Sankce nic moc nepřinesly, říká Babiš. Chtěl by začít obchodovat s Ruskem, iRozhlas: available at https://www.irozhlas.cz/ekonomika/vlada-andreje-babise-obchod-export-zahranicni-trhy_1807081428_per.

Lamoreaux, Jeremy W. (2021): The Trump and Putin Doctrines: Evolving Great Power Tensions Between the United States and Russia. In: Renshon S., Suedfeld P. (eds) The Trump Doctrine and the Emerging International System. The Evolving American Presidency. Palgrave Macmillan, Cham. https://doi.org/10.1007/978-3-030-45050-2_8.

Lavrov, Sergey (2019): Vystúpenie ministra zahraničných vecí RF S. Lavrova na Mníchovskej bezpečnostnej konferencii, Mepoforum: available at http://mepoforum.sk/staty-regiony/europa/vychodna-europa/rusko/vystupenie-ministra-zahranicnych-veci-rf-s-lavrova-na-mnichovskej-bezpecnostnej-konferencii/.

Mackinder, Halford. J (1904): The geographical pivot of history, The Geographical Journal 2004: available at https://www.iwp.edu/wp-content/uploads/2019/05/20131016_ MackinderTheGeographicalJournal.pdf (8 June 2019). 
Mankoff, Jeffrey (2019): Russian Foreign Policy: The Return of Great Power Politics. Plymouth, UK: Rowman \& Littlefield Publisher.

Medvedev Assures Pellegrini that Slovakia Can Count on Russian Energy Supplies (2019): TASR. sk: available at https://www.tasr.sk/tasr-clanok/TASR:20190605TBA02002 (10 June 2019).

Národní akční plán rozvoje jaderné energetiky v České republice (2015): Ministry of industry and trade of Czech republic: available at https://www.mpo.cz/assets/dokumenty/54251/61936/640148/priloha001.pdf (7 June 2019).

National Security Strategy of the United States of America (2017): The White House: available at https://www.whitehouse.gov/articles/new-national-security-strategy-new-era/ (8 June 2019).

Nuclear Power in Hungary (2019): World Nuclear Associan: available at http://www.world-nuclear.org/information-library/country-profiles/countries-g-n/hungary.aspx (13 June 2019).

Pápa Air Base - Main Operating Base (2019): NATO Support and Procurement Agency: available at http://www.nspa.nato.int/en/organization/NAMP/papa.htm (4 June 2019).

Pellegrini tvrdí, že zmluva o spolupráci s USA nie je problém (2019): SITA (Slovenská tlačová agentúra): available at https://domov.sme.sk/c/22080645/pellegrini-tvrdi-ze-zmluva-ospolupraci-s-usa-nie-je-problem.html (3 June 2019).

Pence, Mike (2019): Prejav viceprezidenta USA M. Penceho na Mníchovskej bezpečnostnej konferencii, Mepoforum: available at http://mepoforum.sk/staty-regiony/severna-amerika/usa/ prejav-viceprezidenta-usa-m-penceho-na-mnichovskej-bezpecnostnej-konferencii/.

Péter Szijjártó holds talks with head of US State Department's Energy Bureau (2018): Website of the Hungarian Government - Ministry of Foreign Affairs and Trade: available at https:// www.kormany.hu/en/ministry-of-foreign-affairs-and-trade/news/peter-szijjarto-holds-talks-with-head-of-us-state-department-s-energy-bureau (12 June 2019)

Péter Szijjártó signs Hungarian-American Defence Cooperation Agreement in Washington (2018): Website of the Hungarian Government - Ministry of Foreign Affairs and Trade: available at https://www.kormany.hu/en/ministry-of-foreign-affairs-and-trade/news/peter-szijjarto-signs-hungarian-american-defence-cooperation-agreement-in-washington (12 June 2019).

Poland calls on Russia to put an end to the occupation of Crimea (2017): Polska.pl.: available at https://polska.pl/politics/foreign-affairs/poland-calls-russia-put-end-occupation-crimea/ (4 June 2019).

Premiér Babiš jednal s ukrajinským vicepremiérem Kistionem o reformě Ukrajiny, obchodní spolupráci i energetice (2018): Government of the Czech republic: available at https://www. vlada.cz/cz/media-centrum/aktualne/premier-babis-jednal-s-ukrajinskym-vicepremierem-kistionem-o-reforme-ukrajiny--obchodni-spolupraci-i-energetice--166522/ (6 June 2019).

Premiér jednal s americkým ministrem energetiky o jaderné energii i zemním plynu (2018): Government of the Czech republic: available at https://www.vlada.cz/cz/media-centrum/ aktualne/premier-andrej-babis-jednal-s-americkym-ministrem-energetiky-o-jaderne-energii-i-zemnim-plynu-169872/ (7 June 2019).

Přepis záznamu rozhovoru prezidenta republiky pro První kanál ruské televize (2014): Pražský hrad: available at https://www.hrad.cz/cs/prezident-cr/soucasny-prezident-cr/vybrane- 
-projevy-a-rozhovory/prepis-zaznamu-rozhovoru-prezidenta-republiky-pro-prvni-kanal-ruske-televize-11552 (5 May 2019).

Prime Minister Mateusz Morawiecki's telephone conversation with the Prime Minister of Ukraine Volodymyr Groysman (2018): premier.gov.pl.: available at https://www.premier.gov.pl/en/ news/news/prime-minister-mateusz-morawieckis-telephone-conversation-with-the-prime-minister-of.html (3 May 2019).

Projekt Energetičeskaja strategia Rosii na period do 2030 goda (2008): Institute of Energy Strategy: Source available online: http://energystrategy.ru (5 May 2019)

Putin, Vladimir. (2019): Vladimir Putin made a speech at the plenary session of the St Petersburg International Economic Forum, Mepoforum: available at http://mepoforum.sk/staty-regiony/ europa/vychodna-europa/rusko/vystupenie-v-putina-na-medzinarodnom-ekonomickom-fore-v-petrohrade/.

Řádek, Miroslav. (2017a): Kybernetická bezpečnost' vybraných svetových vel'mocí a Slovenska = Cybernetic safety of selected world villages and Slovakia, in Medzinárodné vztahy 2017, 888-894. Ekonóm.

Řádek, Miroslav. (2017b): Realistická alebo idealistická zahraničná politika USA?, in Ekonomické, politické a právne otázky medzinárodných vztahov 2017, 309-316, Ekonóm.

Ropa a ropné produkty, Bilanční přehled za rok 2016 (2017): Ministry of Industry and Trade of the Czech Republic: available at https://www.mpo.cz/assets/cz/energetika/statistika/ropa-ropne produkty/2017/10/Zprava_Ropa2016_rok.pdf (8 June 2019).

Ropovodná siet' v SR (2019): Transpetrol: available at http://www.transpetrol.sk/ropovodna-siet-v-sr/ (7 June 2019).

Rosatom will continue to supply Slovakia's NPPs with nuclear fuel (2019): Rosatom: available at https://www.tvel.ru/wps/wcm/connect/tvel/tvelsite.eng/ presscenter/news/8dc4d0004a26df93a8d3bf3154a5cfd2 (7 June 2019).

Rozhovor prezidenta republiky pro Parlamentní listy (2015): Pražský hrad: available at https:// www.hrad.cz/cs/prezident-cr/soucasny-prezident-cr/vybrane-projevy-a-rozhovory/rozhovor-prezidenta-republiky-pro-parlamentni-listy-2-11583 (7 May 2019).

Rusi považujú Zemanov prejav v Rade Európy za uznanie anexie Krymu (2017): Aktuality.sk: available at https://www.aktuality.sk/clanok/528748/rusi-povazuju-zemanov-prejav-v-rade-europy-za-uznanie-anexie-krymu/ (5 May 2019).

Russia proposes Slovakia join Nord Stream-2 and Turkstream: agencies (2019): REUTERS.com: available at https://www.reuters.com/article/us-russia-slovakia-gas/russia-proposes-slovakia-join-nord-stream-2-and-turkstream-agencies-idUSKCN1T61FX (8 May 2019).

Russian National Security Strategy (2015): available at http://www.ieee.es/Galerias/fichero/ OtrasPublicaciones/Internacional/2016/Russian-National-Security-Strategy-31Dec2015.pdf (20 June 2019).

S Ruskom ako spol'ahlivým dodávatel'om môžeme nad'alej počítat', potvrdil ruský premiér (2019): Ministry of Economy of the Slovak republic: available at https://www.mhsr.sk/top/s-ruskom-ako-spolahlivym-dodavatelom-mozeme-nadalej-pocitat-potvrdil-rusky-premier. 
Sadecki, Andrzej. (2014): Hungary's stance on the Ukrainian-Russian conflict, Centre for Eastern Studies: available at https://www.osw.waw.pl/en/publikacje/analyses/2014-05-21/hungarys-stance-ukrainian-russian-conflict.

Secretary General praises the Czech Republic's commitment to NATO (2019): REUTERS.com: available at https://www.nato.int/cps/en/natohq/news_153148.htm. (8 May 2019).

Sivý, Rudolf (2014): Fico: Na Ukrajine hrozí vel'ký konflikt, nemyslím ten s Ruskom, SME (02 December): available at https://domov.sme.sk/c/7524733/fico-na-ukrajine-hrozi-velky-konflikt-nemyslim-ten-s-ruskom.html (21 June 2019).

Slovak PM follows Czechs in ruling out foreign NATO troops (2019): REUTERS.com: available at https://www.reuters.com/article/us-ukraine-crisis-slovakia-nato/slovak-pm-follows-czechs-in-ruling-out-foreign-nato-troops-idUSKBNOEF18F20140604 (8 May 2019)

Slovakia and the Czech Republic Reject NATO Bases Ukrajine (2014). Atlantic Council.com, available at https://www.atlanticcouncil.org/blogs/natosource/slovakia-and-the-czech-republic-reject-nato-bases/ (7 May 2019).

Slovensko chce pomôct' pri rekonštrukcii plynárenstva na Ukrajine (2019): SME.sk: available at https://ekonomika.sme.sk/c/22100847/slovensko-chce-pomoct-pri-rekonstrukcii-plynarenstva-na-ukrajine.html (8 May 2019).

Slovensko nikdy neuzná nelegálnu anexiu Krymu, vyhlásil Kiska (2015): SME.sk.: available at https://svet.sme.sk/c/7815090/slovensko-nikdy-neuzna-nelegalnu-anexiu-krymu-vyhlasil-kiska.html (5 May 2019).

Šnídl, Vladimír (2015): Studená vojna sa neskončila. Pozrite si mapu vojenských základní USA a Ruska v Európe, DenníkN: available at https://dennikn.sk/90974/kde-su-najblizsie-americke-kasarne-pozrite-si-mapu-vojenskych-zakladni/ (6 May 2019).

Spykman, Nicholas J. (1938): Geography and Foreign Policy I, American Political Science Review: available at https://www.cambridge.org/core/journals/american-political-science-review/ article/geography-and-foreign-policy-i/7E5E89E490235633DA6110942F01F0B8 (9 June 2019).

Strojaščejesa AES (Строящиеся АЭС) (2019): ROSATOM.ru.: available at https://www.rosatom. ru/production/design/stroyashchiesya-aes/ (5 May 2019)

TASR (The News Agency of the Slovak Republic) (2014): Teraz.sk: available at https://www.teraz. sk/slovensko/fico-vojenska-zakladna-odmietnutie-sr/97092-clanok.html (4 August 2019).

U.S., Poland sign contract on LNG, other topics: U.S. official (2019): REUTERS.com.: available at https://www.reuters.com/article/us-usa-poland-lng/u-s-poland-sign-contract-on-lng-other-topics-u-s-official-idUSKCN1TD297 (20 June 2019).

Ušiak, Jaroslav (2018): Security-related Cooperation among the V4 States. Politics in Central Europe, 14 (2): 39-56.

Waisová, Śárka (2018): The Environmental Situation in the Visegrad Region: Neglect and Insufficient Cooperation in the Face of Serious Environmental Threats. Politics in Central Europe, 14 (2): 57-73.

Waisová, Šárka (2020): Central Europe in the new Millennium: The new Great Game? US, Russian and Chinese interests and activities in Czechia, Hungary, Poland and Slovakia. Revista UNISCI, 54 (October): 29-48. 
WORLDWIDE THREAT ASSESSMENT of the US INTELLIGENCE COMMUNITY (2019): Mepoforum: available at http://mepoforum.sk/wp content/uploads/2019/01/DNI-Worldwide-Threat-Assessment-2019.pdf (15 June 2019).

Zpráva o očekávané dlouhodobé rovnováze mezi nabídkou a poptávkou elektřiny a plynu (2016): Ministry of Industry and Trade of the Czech Republic: available at https://www.mpo.cz/cz/ energetika/strategicke-a-koncepcni-dokumenty/zprava-o-ocekavane-dlouhodobe-rovnovaze-mezi-nabidkou-elektriny-a-plynu-2016--231285/ (8 June 2019).

Ob utverzhdenii Energeticheskoy strategii Rossii na period do 2020 goda. [Об утверждении Энергетической стратегии России на период до 2020 года.] (2003): available at http:// docs.cntd.ru/document/901872984 (13 June 2019).

Jaroslav Ušiak is Associate Professor in International Relations at the Faculty of Political Science and International Relations, Matej Bel University in Banska Bystrica/Slovakia.E-mail:jaroslav.usiak@umb.sk

Lubomír Klačko is a PhD. Candidate at the Faculty of Political Science and International Relations, Matej Bel University in Banska Bystrica/Slovakia. E-mail: klackolubo@gmail.com

Mgr. Ivana Šostáková is a PhD. Candidate at the Faculty of Political Science and International Relations, Matej Bel University in Banska Bystrica/Slovakia. E-mail: ivana.sostakova@gmail.com 